\title{
WHAT IF THE ENVIRONMENT IS A PERSON? Lineages of Epigenetic Science in a Toxic China
}

\author{
JANELLE LAMOREAUX \\ University of Cambridge \\ (D) http:/ / orcid.org/0000-0003-4031-4437
}

The walk from the university toxicology laboratory to the children's hospital is not far; Wang Bo and I have plenty of time to stop at a sidewalk fruit vendor's stand to purchase a watermelon, a gift we will present to the staff at the hospital. Today we will meet with Lin Ming to discuss his life as a medical student, charged with treating infants who have a variety of conditions requiring neonatal surgery. Lin and I know each other from the developmental and reproductive toxicology laboratory where I conducted the bulk of my fieldwork. There, Lin prepared and analyzed samples for studies on the potential epigenetic factors involved in the development of congenital disorders. While Lin's work in the lab centered on test tubes and tissue samples, his professional life in the children's hospital rotates around distressed children and their anxious family members.

Wang, my colleague from the laboratory, and I maneuver through the crowds of parents and grandparents gathered around sidewalk vendors selling balloons and plastic toys for the children being treated inside. On entering the hospital, I am struck by the sheer number of family members that accompany each child. Together, multiple generations sit on every available chair and bench, standing at every corner and window of the waiting room. We board the elevator, where children and infants with bandages and face masks sit on the hips of their caretakers, meeting us at eye level. This is a premier children's treatment center for not only Nanjing residents but also for those living in the surrounding areas 
of Jiangsu and Anhui Provinces - it is always a busy place inside and out, I am told.

As I will soon find out, it was through interactions with the parents and grandparents accompanying patients that Lin developed both his commitment to becoming a doctor and his perspective on the importance of conducting research into the causal factors of birth defects. According to Lin, parents of infants who suffer from congenital disorders tend to blame themselves for their child's ill health. Physicians like Lin try to discourage this guilt and embarrassment, pointing to the many possible causes of the conditions their children face, ones that go beyond individualized behaviors, such as air and water pollution, food safety and availability, and changing lifestyle habits that have accompanied broader shifts in Chinese daily life during the past thirty years of post-Reform and Opening social change. Lin suggests that each of these factors - none of which are the parents' responsibility — could have brought about the disorders he regularly treats.

While Lin's list of factors may have come across as an anecdotal remedy offered to parents in need, the hospital had recently partnered with the local toxicology laboratory to more rigorously investigate the potential causes of birth defects. This local toxicology laboratory, which I refer to as the DeTox Lab, was where I regularly conducted research in 2011, after establishing contact with the lead professor involved in the lab's gene-environment interaction research back in 2008. While this day was my first time visiting one of the laboratory's clinical partners, Lin regularly moved between the laboratory and the clinic. At the time of my visit, he was assisting with a project investigating the potential inheritability of one specific birth defect, Hirschsprung's disease, through a study of the epigenetic mechanisms involved in its development.

Epigenetic research often studies the way in which DNA expression is influenced by extragenetic factors that might have previously been deemed social or environmental, and therefore insignificant to genetic processes. Diet, lifestyle, class, toxic exposures, and other variables once thought to be genetically noninfluential are today believed to play an important role in DNA expression. Epigenetics is often characterized as the study of modifications to the gene that impact gene expression without altering DNA sequence. Moreover, these modifications are sometimes inherited, which has led many to highlight the overlap of current epigenetic theories with Lamarckian ideas about the inheritance of acquired characteristics (Jablonka and Lamb 1999; Rapp 2005). Neo-Lamarckian theories were largely dismissed in the second half of the twentieth century, when the gene became increasingly fetishized and imbued with deterministic qualities that led 
DNA to be interpreted as the code of life (Franklin 1995; Keller 2002). Since the turn of the twenty-first century, however, an increasing number of scientists from many disciplinary backgrounds have moved away from a perspective that views genes as autonomous, deterministic hereditary units and toward explorations of the immediate and transgenerational impacts of epigenetic factors. As anthropologist Margaret Lock $(2007,62)$ states, such explorations "have exploded the central dogma on which molecular biology was founded," leading to what is often characterized as the postgenomic age.

Conrad Waddington (2012) first used the concept of epigenetics in 1942 to express interest in the complex of developmental processes between the genotype and the phenotype, which he hypothesized contributed to the unpredictability of genetic inheritance. After decades of near dormancy, in the twenty-first century epigenetics has become a catchphrase for a number of genetic processes that do not adhere to a strict notion of individual hereditary units that autonomously pass from individual to individual, contrasting with Mendelian genetics. Yet even with a generally agreed-on characterization of epigenetics as "a shift in focus from gene sequence to gene expression" (Landecker and Panofsky 2013, 335), today the term is often "a muddle" (Keller 2010, 5) and at best describes a broad and somewhat ambiguous category of scientific theories and research practices. It is, therefore, helpful to think not only about what epigenetics is but also about what epigenetics does, as well as about how epigenetic research is conducted.

Between 2008 and 2011 I conducted fieldwork in China, interviewing and observing a small but growing group of toxicologists involved in epigenetic research at the Nanjing Institute for Medicine and Science (NIMS). ${ }^{1}$ These developmental and reproductive toxicologists primarily conduct what social scientists Julie Guthman and Sarah Mansfield (2013) describe as "environmental epigenetics," or epigenetic research that studies the health impacts of xenobiotic chemicals, distinguished as foreign, unexpected, or not naturally present in an organism. In addition to environmental epigenetics, the toxicologists at NIMS, like many natural scientists involved in epigenetic research, also attempt to isolate the specific epigenetic mechanisms involved in bringing about alterations to DNA expression. Through attention to the DeTox Lab's studies of epigenetic mechanisms, as well as to the lab's proposed future birth-cohort studies of birth defects, in this article I further explore the idea of the environment at work in intergenerational epigenetic studies, which often goes beyond understanding the environment as a nonhuman xenobiotic chemical, instead viewing the environment as a person. 
This understanding of the environment as a person, however, is not based in an idea of persons as autonomous individuals. In the DeTox Lab's research, and in my own usage, which follows from observation and an analysis of the lab's epigenetic studies, the environment is a person who always stands in relation to other personal and nonpersonal environments of exposure. This definition of the environment more deeply resonates with what some anthropologists have interpreted as fundamental organizing principles of everyday Chinese life, such as a more relational notion of personhood (Yang 1994) and a more porous understanding of the relationship between the human and the environment (Choy 2011; Tu 2001; Zhan 2011). In the laboratory where I conducted research, these preexisting models of transgenerational, biosocial relationality are newly configured as responses to changing economic, social, and environmental conditions. Developmental and reproductive toxicologists conducting epigenetic research in China today highlight the connections between humans across generations, with and as environments, thereby reasserting a sense of intergenerational connectivity and responsibility in a moment of China's increasing individualization (Kleinman et al. 2011; Yan 2009) and chemical toxicity through a definition of the environment that accounts for such complex lineages. The environment is, then, a lineage of personal and chemical exposures.

Recent social scientific studies suggest that in epigenetic research and media interpretations of epigenetic studies, mothers are often understood as the primary environment impacting the developing fetus through interactions with genes (Pickersgill et al. 2013). Many have argued that when mothers are understood as what Hannah Landecker (2011) calls environments of exposure, it renews and even exaggerates preexisting ideas of maternal responsibility for child health (Richardson et al. 2014; Warin et al. 2012). A mother's behaviors, lifestyle, and dietary choices are now seen to impact not only the immediate development of the fetus but also the fetus's future adult health as it relates to a number of conditions, from asthma to obesity. Even more pressure is added when epigenetic research suggests that a fetus's germ cells, the potential future gametes of the fetus, may also be impacted by the behaviors of previous generations. Instead of saying you are what you eat, popular accounts of epigenetics today stress that you are what your mother, or even your grandmother, ate.

While recognizing the potential for epigenetic research to increase the maternal burden of responsibility for disease, in this article I argue that some epigenetic research, such as that conducted by the DeTox Lab, might also encourage a reimagining of disease responsibility as existing in relations and configurations 
that move beyond individualized notions of personhood. Through an ethnographic portrayal of the research and treatment of congenital disorders in Nanjing, I show how the DeTox Lab's studies regards people (generally mothers) not only as environments directly impacting the health of the next generation of offspring but also as environments influencing multiple future generations. Furthermore, chemicals to which these generations were exposed are regarded as environments potentially having an impact on future genetic expression. The DeTox Lab's epigenetic research thus deindividualizes ideas of the environment as a person, and of disease responsibility, in and through ideas of transgenerational, extragenetic inheritance. Such findings raise the stakes of epigenetic research for the social sciences, showing that some epigenetic studies have the potential not only to disrupt boundaries between the biological and the social but also to challenge assumptions of individuality, autonomy, and personhood that underlie some of the most strongly influential genetic and social theories of the twentieth century.

\section{IS GENE TO INDIVIDUAL AS ENVIRONMENT IS TO SOCIETY?}

Amid growing bioscientific emphasis on epigenetic research, many social scientists have expressed excitement about the potential for epigenetics and similar systems sciences to inspire a new era of integrated biosocial research (Ingold and Pálsson 2013; Pálsson 2007). Epigenetics potentially opens up the possibility of an approach that has been described as genetics's "anthropological turn" (Goodman, Heath, and Lindee 2003, 3). Genetic explanations for characteristics, behaviors, or diseases are now being supplemented or displaced by notions of disease causality that consider the impacts of social determinants of health long studied by social scientists of medicine, such as poverty, lifestyle, and even psychosocial stress (Rapp 2005). Many social and natural scientists alike have expressed cautious excitement about the material and theoretical overlap of the social or environmental with the biological, and are discussing epigenetics as a new way into longstanding questions about nature and nurture.

One of the first anthropologists to address epigenetics was Marilyn Strathern (1991, 585-88), who proposed at least two alternatives to the Euro-American folk model of individual and society "replicated or miniaturized" within genetic and epigenetic thinking. First, she provided a cross-cultural reference, describing how Melanesians conceive of themselves not as independent persons but as persons always in relation to other persons, or "dividuals." Second, she brought this dividual back to a discussion of epigenetics. After listening to a presentation on the revolutionary potential of epigenetics at the 1990 meeting of the British 
Association for the Advancement of Science, she followed the lead of a gynecologist also in attendance to ask: what if the epigenetic environment with which the gene interacts is another person (for instance, the mother hosting the impressionable embryo)? This question disrupts the relationship commonly depicted between the isolated gene and the encroaching epigenome and between a freestanding individual and an enveloping society. It is also a question frequently asked by the reproductive toxicologists I studied.

Strathern's early analysis of an emerging epigenetic science argues that no matter how revolutionary epigenetic research may seem, it relies on a theoretical foundation similar to previous modes of genetic thinking. She argues that even when thinking beyond the gene, epigenetics perpetuates a distinct understanding of the relationship between individuals and society. Pointing to consistencies between epigenetic and genetic research, Strathern presents an analogy: the gene is to the individual as the epigenome is to society. Like the individual, the gene in epigenetic research is still thought of as a freestanding entity, impacted by (but standing apart from) what exists outside it. Strathern argues that as with society, which is often understood in the social sciences to include everything that exists beyond the individual, epigenetic environments include potentially everything beyond the gene. Moreover, both environment and society are abstract concepts concretized through examples of their parts, such as mountains or institutions.

In the DeTox Lab's epigenetic research on male reproductive health issues such as male infertility, the environment is concretized in a variety of ways - as a risky occupational setting, an estrogenic food, or an endocrine-disrupting chemical injected directly into the body of an animal in the laboratory (Lamoreaux 2013). In the scientists' studies of congenital disorders, however, the potentially impactful extragenetic environment is first another person, specifically a mother who influences the fetus. Social scientists have criticized such an understanding of the mother as the primary epigenetic environment for reinforcing maternal blame (Mackendrick 2014; Richardson et al. 2014; Warin et al. 2012). However, as I will discuss in the final section of this essay, such criticisms assume that when the environment is a person, this person is an isolated individual (the mother). As I will show, in the epigenetic research on birth defects conducted by the DeTox Lab, the environment is not just a single person; rather, it comprises a series of people embedded and embodied in the sometimes toxic human and nonhuman environments of the past and the present. ${ }^{2}$ A mother is more and less than an individual, interconnected to and instantiated through the many potentially toxic environments that surround her and her fetus. When the environment with 
which the gene interacts is both another person and the toxic chemicals to which present and previous generations were exposed, what models of disease causality and responsibility are reinforced and reconfigured?

\section{SITUATING CONGENITAL DISORDERS}

The DeTox Lab's research began in the mid-1990s by looking into how direct low-dose exposures to toxic chemicals potentially impact male reproductive health. Fifteen years later, the scientists' research has expanded in many ways, including toward a focus on how indirect exposures to toxins may be linked to the intergenerational transmission of congenital disorders, especially those thought more common in Asian populations. Though not known for the accuracy of its statistical data (Liu 2012), the Chinese government reports that the nation faces high rates of birth defects, with reported cases estimated as having increased by 70 percent between 1996 and 2010 (People's Republic of China Ministry of Health 2011). While the above-cited Ministry of Health report does not speculate as to the cause of this dramatic rise, scientists based both in and beyond China have recently conducted research that points to indoor and outdoor air pollution, water pollution, and persistent organic pollutants such as the pesticide dichlorodiphenyltrichloroethane (DDT) as potential causal factors in China's high rates of congenital disorders.

Of course, what connects each of these individually researched causal factors is the large growth in China's economy during this same time frame. Following Reform and Opening (găigé kāifàng) policies that officially began in 1978, China has undergone massive social and economic change, especially in eastern provinces such as Jiangsu. While many indicators of health and wealth have improved during the past thirty-five years, including national GDP, literacy, maternal mortality, and longevity, new problems have also surfaced, including chronic diseases and illnesses related to environmental pollution such as cancers (Lora-Wainwright 2013) and infertility (Lamoreaux 2013). Despite often unenforced, and at times nonexistent, pollution regulation and the prioritization of economic growth over human health, in some ways the government remains committed to advancing the quality of China's population, alongside raising its economic growth. Since the early days of Reform and Opening, the government has focused not only on attempts at rapid industrialization but also on improving population quality (rénkǒu sùzhi) through measures of aptitude, physical form, class, health, education, and a host of other supposed quality indexes (Anagnost 2004; Dikötter 1998). Raising population quality was institutionalized as a national goal in the late 1980s, around 
the same time that family-planning restrictions were put in place (Dikötter 1998; Greenhalgh 2008). Today, government policies and citizen concerns continue to stress the improvement of the population through both social and biological measures. Government campaigns aimed at encouraging parents to focus limited resources on fewer children, as well as prenatal health programs meant to increase fetal health and thereby population quality, continue to impact Chinese families today (Zhu 2013). The government's funding of the DeTox Lab's research on congenital disorders might also be interpreted as an effort to improve population quality. If results eventually show strong associations between pollution and birth defects, the DeTox Lab's research would, however, highlight a negative impact of the past thirty-five years of largely unregulated industrial development, and the wide array of toxic exposures brought with it, on human development at economic, social, and biological levels.

In the context of epigenetic research, the stakes of such findings are even higher, for here toxins are thought to potentially impact not only the generation currently in utero but also generations further in the future. As discussed in the introduction, the DeTox Lab conducts investigations into the potential links between toxic chemicals and epigenetic alterations associated with birth defects in affiliation with regional children's hospitals that treat a variety of congenital disorders. The laboratory researcher Wang Bo and I visited one of these hospitals, located within Nanjing, to speak further with his colleague Lin Ming, a physician in training who assists the DeTox Lab with its research.

\section{AT THE CHILDREN'S HOSPITAL}

On a spring day in 2011, Wang and I enter the neonatal surgery unit and present the children's hospital staff with our gift, the watermelon. After quick introductions we put on white overcoats to begin our tour of the unit. In the hospital setting where Lin spends most of his time, his quiet laboratory demeanor becomes that of a confident physician in training. Lin is clearly in his element; Wang and I are clearly out of ours. The lead nurse joins us as we move through the five or so patient rooms. In each room there are between three and five infants, accompanied by parents and often grandparents. Between nine and fifteen people occupy each space — some adults sleep, some sit on makeshift and hospital beds, some cradle their babies who are either awaiting or recovering from surgery. All are there for the duration of their infant's stay, only stepping outside and into the Nanjing city streets for food or a bit of exercise. 
As we move from patient to patient, parents and grandparents assist in removing blankets and surgical dressings to allow us to view the infants' bodies and fleshy traces of operations. Parents and grandparents watch me as, or more, carefully than I am watching Lin and the head nurse moving from patient to patient. I do my best to remain stoic, afraid I might express my sadness and fear. I save my questions for afterward and nod as I learn about each infant: their condition, whether or not surgeries have been successful, and when they will most likely be discharged. One child has recently had a mass removed from her head. Another was born without an anus. Many are at different stages of recovery after having been surgically treated for rectal or intestinal deformities, the most common conditions diagnosed in the unit.

After our patient visit we wash our hands and sit in a small back room where the lead nurse serves us the watermelon Wang Bo and I have brought. The prearranged interview feels more like a conversation between colleagues; Wang Bo is just as interested in the discussion as I am. Wang has been researching the epigenetic mechanisms of reproductive diseases for years now, but unlike Lin, he does not interact with patients. Since spending a summer working in the toxicology laboratory as an undergraduate, his plan to follow in his mother's footsteps and become a doctor changed. He has now worked as a research scientist for more than five years, and in all that time this is his first trip to the children's hospital where some of the tissue and blood samples used in the laboratory are gathered. His curiosity catches me off guard; his excited inquisitiveness seems to surprise even him. He is brimming with questions about patients, parents, and procedures. What conditions do they face? What treatments do they receive? How often do they survive? He does not ask what causes the conditions because, like Lin, he knows that the answer to this question is multifaceted and largely unknown.

While Lin contributes to the DeTox Lab's epigenetic research on congenital disorders, he spends most of his time treating those patients in need of neonatal surgery. Frequent patient and parent interactions seem to have created a kind of ethical commitment to his work, one that surprised Lin himself and that he was not sure his coworkers shared. This came through in a story he told of a night when he was on call. A couple came to the hospital with their newborn son. Desperate for some kind of answer to their child's inability to eat, sleep, digest, or pass a bowel movement, they had traveled from the Anhui countryside to Nanjing. They pleaded with Lin to save their child's life. After hours of examinations and tests, Lin was finally able to diagnose the child with an intestinal 
abnormality and rush him to surgery, where physicians performed a simple procedure. He was proud of his accomplishment, of his correct diagnosis. But he said the moment that truly changed him was when he went to tell the parents the news. On hearing what had occurred, both parents fell at his feet in what Lin interpreted as the ultimate symbol of gratitude.

While he told me this story, Lin himself was moved. He continued reflecting: this kind of interaction made him realize he was happy to be a doctor. Regardless of the low pay, long hours, and frustrating patient interactions that accompany his career, the profession brings him great joy. The elation that comes from helping others is something he hopes his generation of Chinese students and professionals will also find. Yet in actuality, he thinks his peers are much more concerned with making money and buying a house (practically a requirement for anyone hoping to marry, Wang adds). After a pause, Lin second-guesses himself, giving his peers the benefit of the doubt. Many of them are from the country, he says, so the idea of buying a house in the city is so far-fetched that they feel they must put all their energy into such material pursuits. For Lin, the ethical expectations of today's youth must be couched within an understanding of the importance of geography and opportunity in China. Geographic separations, which largely represent economic divisions as well, keep certain graduate students from pursuing careers for more than the financial advantages they might bring, which is seen as their only hope for fulfilling familial duties. Wang agreed: without a career there is no money, without money there is no marriage, without marriage there is no child.

In Lin's description of his peers, one can feel both a critique of increasing individualism, or at least of the single-minded pursuit of money, among young adults in China, as well as an understanding that such individualization (Yan 2009) results from broader environments - socioeconomic circumstances and gendered kinship expectations that shape career trajectories and professional motivations. It is this second understanding of the person, as always in relation to other human and nonhuman environments, that also exists within the DeTox Lab's research on one specific congenital disorder, Hirschsprung's disease.

\section{RESEARCHING HIRSCHSPRUNG'S DISEASE}

Hirschsprung's disease (HD) is often described as a disconnected communication signal or power line in the intestinal tract. Infants diagnosed with HD lack nerve cells in their intestines and are unable to send messages or transmit signals that should move fecal matter through the colon and out the rectum. This 
leads to constipation, which can then lead to a distended abdomen, malnutrition, infection, and even death. The most reliable symptom of HD is a lack of bowel movement in the first forty-eight hours of life. Yet many infants with the disease do have occasional bowel movements, often making the condition difficult to diagnose. The disease can be life threatening if left undiagnosed or untreated, and it is said to affect one in every five thousand births worldwide (U.S. National Institute of Health 2012). It has been argued that these statistics vary by ethnicity; a Taiwan-based study claims that for every 2 Caucasians, 2.8 Asians were found to have HD (Chin et al. 2008). National concerns about the reproduction of quality Chinese bodies, then, likely informed the DeTox Lab's decision to focus on this particular condition, as did the fact that males are four times more likely to be diagnosed with HD than females (Emison et al. 2005). ${ }^{3}$

To conduct research on the possible epigenetic mechanisms involved in HD's pathogenesis, the DeTox Lab partnered with a children's hospital in Nanjing that treats about seventy-five HD-diagnosed infants per year. While Lin seemed to regard his time working at the hospital as difficult and exhausting, on another day when I saw him analyzing specimens in the DeTox Lab, he described the laboratory aspect of his work as a painful hardship (xīnkǔ), with long hours and much repetition. As the primary technician on one of the DeTox Lab's investigations into HD, Lin must turn his attention to epigenetic mechanisms in this setting. Epigenetic mechanisms are now thought to regulate gene expression, a process that occurs through a variety of activities including DNA methylation (the addition of methyl groups - a group of atoms, three hydrogen and one carbon - to DNA). Methylations block the transcription of DNA to RNA, a necessary process in gene regulation, but a process also associated with some health conditions, such as HD. By investigating methylation patterns, the DeTox Lab can analyze whether genes thought to be related to the production of neural crest cells (which migrate to the intestines) have been deactivated via methylation. ${ }^{4}$ The DeTox Lab has found that genes involved in the formation of critical colonic nerve cells are turned off by specific DNA methylations. Once turned off or deactivated, intestinal nerves are less likely to develop and bowel motility is reduced - a conclusion the scientists reached by comparing the methylation patterns derived from their analysis of colon tissue and blood samples from patients diagnosed with HD to a control population's samples. This research establishes that HD, and potentially other birth defects impacting infants in China and around the world, might be epigenetically inherited. It is a first step toward studies of HD that will not only pinpoint the mechanisms through which epigenetic transmission occurs but will also in- 
dicate environmental exposures that bring about such epigenetic modifications in the first place. ${ }^{5}$

To study the toxic exposures that lead to modifications such as DNA methylation, the DeTox Lab has also designed a multiprovince birth-cohort study. Birth-cohort studies are often considered ethical to conduct on human populations because they are so-called natural experiments. They do not create, but instead monitor, the activities, behaviors, or physical/social/psychological attributes of their research subjects. Such studies generally track individuals over the life course, claiming to observe research subjects rather than influence them through exposure to certain influences or research variables. In epigenetic research, birthcohort studies are used to investigate the potential transgenerational impact of epigenetic inheritance in humans, both by monitoring the biological samples of multiple generations over time and by collecting detailed information about the environments in which people work and live.

In the DeTox Lab's research, samples and their accompanying environmental characteristics have been gathered from multiple generations of individuals: infants, parents, and grandparents. Blood, urine, and semen samples that will eventually be used in studies of HD and other conditions come from patients at university-affiliated hospitals in Yangtze River Delta provinces and beyond. When these biological samples are taken, surveys simultaneously collect information regarding occupation, residence location, and potential toxic exposures. Additionally, researchers gather general air and water pollution figures for the surrounding areas. Lab director Zhang Zhiyuan's hope is that this broad collection of samples will eventually allow him to correlate methylation patterns now known to be involved in the development of HD with particular environmental exposures. Here, as in the epigenetic research analyzed by Hannah Landecker (2011), environments are understood as exposures. Yet instead of concentrating on environmental exposures that relate to the individual behavioral characteristics of mothers, such as dietary intake, environments come in a variety of human and nonhuman forms. Data is collected in a number of ways - biological samples, written surveys, and chemical analyses - and these various versions of the environment are considered in and through one another.

Though publications have yet to result from this sample and data gathering, when statistically significant patterns do eventually emerge between patients with HD and past generations' exposures to specific environments (variably defined), Zhang hopes to provide convincing evidence for the inheritable impacts of environments. Such epigenetic inheritance requires the understanding of environment 
as person, as the mother becomes a vessel through which exposures and their associated methylations travel. But it also encourages an understanding of the epigenetic environment interacting with genes as more than simply an individual. This research places the mother of an infant that suffers from HD within a context of both human and nonhuman environments. Even when the environment is a person (the mother), this person will be seen in relation to the many additional environments that surround her, both personal and impersonal. These could be human relatives from previous generations, as well as industrial, water, or air pollutants, pesticides or other occupational exposures. Through these concentric circles of environments, the DeTox Lab's research draws attention to the toxicity of China's recent industrial, economic, and social change on many scales, going both back in time and outward from the interior genetic structure to the surroundings of the fetus.

The lab attempts to address how environments of rapid social change within which ancestors lived, worked, and reproduced have epigenetically transformed the bodies of contemporary and future generations - a project not dissimilar to the work of anthropologists such as Judith Farquhar (2002, 17), who claims that generational differences in China exist "not so much in ideals as they are in bodily dispositions, inculcated by the conditions of everyday life in a postsocialist reform process that quietly evolved, beneath the hubbub of a much debated politics." This quiet evolution of bodily dispositions and developments will be further researched by the DeTox Lab in future multiprovince birth-cohort studies, offering an epigenetic interpretation of how differences and similarities between Chinese generations and their environments are embodied. Rapid social change, then, could be seen at the epigenetic level.

\section{LINEAGES OF EPIGENETICS}

Conducting such birth-cohort studies will not be easy, yet Zhang states that precisely the difficulty of investigating toxic exposures in China drew him to this research. Complexity - in the form of multiple, overlapping exposures with potential indirect and intergenerational effects — is his starting point, and a grounding assumption of the DeTox Lab's approach to disease causality. As stated by Zhang, HD is understood through a non-Mendelian notion of genetic disease causation, largely differing from the kind of fixed and predictable genetic relatedness that eventually characterized what Evelyn Fox Keller (2002) has called the "century of the gene." 
According to Keller (2002), even after the 1900 rediscovery of Gregor Mendel's rules of inheritance, which stated that inheritance works through discrete units passed from parent to offspring, the first four decades of the twentieth century were riddled with questions about what actually constitutes a gene. As the century progressed with Oswald Avery, Colin MacLeod and Maclyn McCarty's 1943 identification of "DNA as the carrier of biological specificity," then James Watson and Francis Crick's convincing 1953 announcement that "genes are real molecules" made up of deoxyribonucleic acid (DNA), consensus began building around the constitution of the gene. "Thus, by midcentury," Keller (2002, 3) writes, "all remaining doubts about the material reality of the gene were dispelled and the way was cleared for the gene to become the foundational concept capable of unifying all of biology." While scientists in China have certainly been conducting genetic research for much of the past century, in this section I discuss how their research reached a different understanding of what constitutes the gene, or at least came to an understanding of the gene's centrality by different means.

As historian Frank Dikötter $(1992,1998)$ has shown, after the fall of the Qing Empire in 1911, the Republican era ushered in support for China's modernization, particularly through science. As genetics and embryology were taken up, ideas of so-called soft inheritance gained popularity, accompanied by a burgeoning commitment to strengthen the Chinese race and nation (mínzú) through eugenics and social Darwinism. Even as members of the solidifying nation were judged in fixed hierarchical states dependent on their supposed nature, according to Dikötter $(1998,70)$, they were still viewed as part of a collective to which they were subordinate, "as self-disciplining cells subordinated by the larger collectivity." The selective embrace of biological and genetic thinking expressed and reinforced a simultaneous feeling of increasing responsibility for one's individual health and for contributing to the quality of the national population in China during the Republican era. According to Dikötter (1998), this shared sense of an individual self-discipline and national duty was a reconfiguration of neo-Confucian ideas of self-cultivation, institutionalized through medical discourse. In the United States, neo-Lamarckianism, which emphasized the plasticity of inheritance and the environment's role in evolution, was held to be in opposition to a Mendelian notion of fixed genetic characteristics (Raffles 2007). While Mendelian genetics dominated scientific circles, neo-Lamarckianism was largely deemphasized by the beginning of World War I in Euro-America (Jablonka and Lamb 1999; Stern 2005). In Republican China, however, these two approaches to genetics were not mutually exclusive. In growing explorations into the science of heredity (yí- 
chuánxué), neo-Lamarckianism was embraced alongside Mendelian genetics "in a holistic approach which stressed the interdependence of nature with nurture and the subordination of the individual to the nation” (Dikötter 1998, 118).

This changed after the Communist Party took formal control in 1949, when Mendelian genetics was denounced as bourgeois science and affiliated with the eugenic campaigns of Adolf Hitler, as well as the hegemony of Western science. Following Soviet scientific trends, the party instead adopted Lysenkoism. In his 1951 book Heredity and Variability, Trofim Lysenko (2001) described the science of heredity as a field that should include the environmental conditions necessary for a living body to develop, not just the genetic traits passed from parent to offspring. Like neo-Lamarckianism, Lysenkoism stressed the malleability of inheritance and the responsiveness of nature to environments. Lysenko $(2001,7)$ emphasized the "relation of an organism of a given nature to its environmental conditions." In the late 1940s, under the influence of Soviet science, Lysenkoism became the primary form of research into heredity in China. The geneticist Ching Chun Li (1950) published a short article in the Journal of Heredity capturing the conflict over Lysenkoism from the perspective of a U.S.-trained Chinese Mendelianist. "Even with unlimited patience," Li (1950, 91) writes, “my colleagues and I have been unable to save the science of genetics from its death in China. The situation becomes one in which one must declare his allegiance to the Lysenko theory or leave. The latter has been my choice." Sympathetic to Li, both for his displacement and for being on what he considers the right side of science, the historian Laurence Schneider (1989) claimed that Lysenkoism delayed or prevented decades of China's scientific potential. ${ }^{7}$ China's Lysenkoist history, for Schneider, proved a cautionary tale through which one might see the ways in which government and party politics stymie scientific progress.

The explicit and intentional intertwining of science and politics in China during this period of Mendelian rejection was deeply troubling to $\mathrm{Li}$ in 1950, as well as to Schneider in 1989, shortly after China's Reform and Opening. Schneider argues that Lysenkoism was adopted in China because this theory of hereditary adaptations to environmental changes fit in with socialist dialectical materialism. Lysenkoism folded the history of the Chinese people into the history of the material world that surrounded them, arguing that plants and potentially human bodies would carry histories within them (with the understanding, of course, that humans make history). Schneider celebrates that since Reform and Opening Chinese society has once again opened itself to a science driven not by politics, but by truth. Yet Schneider's glorification of the return of Chinese genetics to an 
apolitical embrace of genetic theories dominant in the West masks the more implicit political and theoretical commitments that underlie Mendelian genetics. ${ }^{8}$ Mendelian genetics were rejected in China not only because they were dominant in Western countries but also because of the implicit values and epistemic presuppositions that this approach to genetics stresses. In particular, communist governments of the Soviet Union and China rejected the premise of nature outside human agency (Shapiro 2001), including the Mendelian premise of heredity based on autonomous units passed through isolated individuals.

While the Chinese state still heavily criticizes individualism today, many scholars argue that the individualization of post-Mao (and post-Deng) China is underway. Anthropologists in particular have shown the results of China's increasing capitalist society. Market reforms and changing lifestyles resulted first in an untying of individuals from the state (Yan 2009), and then in the rapid growth of desires (Zhang 2015) and desiring subjects (Rofel 2007) in the face of conflicted understandings of the self (Liu 2002). Such individualization seems to correspond with the post-Reform and Opening rise in genetic determinism and can be found in concerns about population quality as, for instance, expressed through government-sponsored prenatal screening campaigns for single-gene disorders. The sociologist Zhu Jianfeng $(2013$, 537) argues that such prenatal screening, which often gives vague or unreliable results, now constitutes an individualized responsibility placed on couples in China. Moreover, it is a technological burden to be endured, unsurprisingly, by the woman's body (Rapp 1999; Thompson 2005). Here, in another reconfiguration of individual self-discipline and national duty institutionalized through science and medicine, the Chinese state both invests in and disentangles itself from a collective, partially shifting the state's burden of fulfilling national population-quality goals from the state to individual parents-inthe-making. While Zhu contends that such shifts expose the increasing neoliberalization of China, the anthropologist Susan Greenhalgh (2009, 205) argues that "the familiar biopolitical story," which includes an individual body/subject that emerges from capitalism, "is Eurocentric" and does not capture the ways in which concerns with population continue alongside individualization in China. In the next section I explore how this simultaneous emphasis on individuals and populations, perhaps sustained since the early Republican era, can be seen in the motivations and practices of toxicologists conducting epigenetic research in China. I ask how the understanding of epigenetics in a Chinese context might lead to a different social scientific understanding of the kind of personhood at work in some epigenetic research. 


\section{EPIGENETIC IN/DIVIDUALISM}

Now well into the first decades of the twenty-first century, social scientists primarily focusing on Euro-America utilize ideas of responsibilization (Clarke et al. 2003) and neoliberal science and health care (Rose 2009) to critique epigenetics, concentrating on the ways in which epigenetic research reinforces individual, maternal responsibility for fetal and child health. Social scientists have described epigenetics, or at least its portrayal in media and by public health practitioners, as a new iteration of a longstanding pattern that blames mothers for the conditions, abnormalities, or defects found in their fetuses. For instance, as illustrated through ethnographic work on prenatal screening (Rapp 1999) and preimplantation genetic diagnosis (Franklin and Roberts 2006), scholars have shown that mothers are often blamed for single-gene genetic disorders, which might be a by-product of such tests utilizing female bodies and bodily fluids (Thompson 2005). Epigenetic theories of disease causality can reinforce these patterns of maternal blame for bodies gone awry by turning individual maternal behaviors or lifestyle choices into toxic exposures that impact fetal health (Mansfield 2012; Warin et al. 2012). Epigenetic research and its media representation in the United States and Australia have depicted the responsibility for epigenetically inherited conditions as the product of individual maternal behaviors such as smoking (Warin et al. 2012) or of essentialized behavioral patterns such as dietary intake (Mansfield and Guthman 2015). Epigenetic research that draws attention to, and only to, the mother as the source of future disease causality is certainly limited by assumptions of individuality underlying such research.

The material-semiotic interworkings of this logic of maternal blame (see Haraway 1991) rely on an assumption of two individuals - a mother, depicted as a badly behaving vessel, and a developing fetus, the victim of the mother's exposures and behaviors. Working through an emphasis on the uterine environment, the mother is figured as the primary site of "epigenetic becoming" (Mansfield and Guthman 2015, 6), where and when infants simultaneously archive the past and become the future. The mother, whose diet or behavior has impacted the fetus, is plucked out of any type of context_-social, environmental, national, chemical_-and turned into an individually responsible being, stripped of her surroundings (Landecker 2014). As stated by Martyn Pickersgill and colleagues (Pickersgill et al. 2013, 437): "In effect women are framed as the first environment for children, potentially activating and augmenting a range of moral discourses and subjecting [women] to (increased) scrutiny.” 
The interpretation that women actually become the environment in epigenetic research resembles the idea proposed by Marilyn Strathern in 1991. However, instead of considering it problematic, Strathern saw the person-environment collapse occurring in some epigenetic studies as a potential means to challenge the very concept of the individual at the heart of so much genetic thinking. I add that this collapse, where and when the environment becomes a person, also has the potential to disrupt the individualism at the heart of notions of "epigenetic responsibility" (Hedlund 2012). In the Chinese setting I researched, the cause and solution to epigenetically linked problems were not "narrowed to the individual" (Warin et al. 2012, 370) or to the spatiotemporal coordinates of the uterine environment (Mansfield and Guthman 2015; Guthman and Mansfield 2013). Instead, proposed birth-cohort studies, physician interactions with patients, and a focus on toxins that result from industrialization recontextualize the fetus in time and space, placing "it back into the uterus, and the uterus back into the woman's body, and her body back into its social space" (Petchesky 1987, 287). In terms more often used in characterizations of Chinese settings, the fetus is placed at the center of concentric circles of interaction.

Concentric circles have often been used in classical Chinese texts to describe the multiple scales of human relationships, where the self lies at the center, followed by the family, community, country, and, eventually, all of humanity at the outer limit (Tu 2001). Sociologist Fei Xiaotong's (1992, 63) famous description of Chinese kinship likens interpersonal relations in China "to the concentric circles formed when a stone is thrown into a lake." Moreover, China and East Asia more generally have been long characterized by anthropologists as places that do not think of bodies in isolation (Chen 2003; Kleinman 1981; Lock and Farquhar 2007; Scheper-Hughes and Lock 1987). Instead, there exists a long history of diagnosing and treating the social causations of bodily illness through an understanding of co-constituted human-environments (Tu 2001; Zhan 2011). Relational ideas of personhood like those found in the DeTox Lab's epigenetic research have characterized social scientific models of Chinese life for a long time. Margaret Lock (2015) has even suggested that the connection between Chinese understandings of the body and epigenetics could be more direct, noting that at the time when Conrad Waddington was developing his theory of epigenetics, he was regularly in conversation with the Sinologist and fellow embryologist Joseph Needham. This assertion does not mean to explain the DeTox Lab's approach to epigenetic research as simply a product of supposed Chinese thinking. The notion that there exists a singular or timeless Chinese understanding of the body, self, 
or personhood as relational has been thrown into question, most recently by anthropological research on rapid post-Reform and Opening social change, which shows that individualization, consumerism, and new kinship formulations are increasingly occurring in China. But perhaps the DeTox Lab is drawing on longstanding relational modes of understanding social life, as well as longstanding values related to the interconnection of humans and environments, to criticize this more recent individualization and responsibilization in China.

I interpret the DeTox Lab's research as an effort to reemphasize connections between inner and outer environments, ancestors and future generations. This recontextualization of the fetus into concentric circles of multiple human and nonhuman environments is, at least, what the medical student Lin hopes to communicate to the families of his hospital patients. According to Lin, families who travel to the children's hospital from rural areas of Jiangsu or surrounding provinces are often embarrassed by their infant's deformities, especially when they have no anus. Lin believes this shame derives from the traditional or Buddhist beliefs of rural parents, who understand their children's birth defects as retribution for parents' bad deeds in past lives or their lack of filial piety. ${ }^{9}$ As a physician, Lin hopes that his research on the potential epigenetic mechanisms involved in the transgenerational inheritance of birth defects will encourage parents to stop blaming themselves for their children's conditions. He and other members of the DeTox Lab conduct epigenetic research not to bring about the responsibilization of the individual but to offer a response to China's rapid social, economic, and environmental change by understanding how and which toxic exposures are epigenetically inherited. Here, to understand the environment as a person is to understand the person as always in relation to other environments and peopleand therefore only able to take partial responsibility for the health of present and future generations.

Lin hopes such displacement, both from the present to previous generations and from patients' traditional beliefs to the science he practices, will ease the sense of responsibility that burdens so many parents. Likely Lin paints too simplistic a distance between his scientific understanding of HD and patient interpretations of their infant's condition. Yet Lin's thoughts on this issue offer a nuanced contrast to critiques of epigenetic sciences that claim such research furthers individual, maternal responsibility for fetal health. In Lin's research and treatment practices, the epigenetic environment is not individualized but multiplied (see Mol 2002); it is made to speak back to feelings of responsibility expressed by his patients' parents. Such research and treatment practices show that 
an epigenetic understanding of disease causality can be, in some instances, a means of thinking beyond the individual.

\section{ENVIRONMENTS AS PERSONS?}

If the environment in epigenetic research is a person, what kind of person is it? In contrast to epigenetic research that focuses on finding evidence to prompt interventions into maternal behaviors or lifestyles such as smoking or diet, the DeTox Lab's research uses epigenetic research techniques to reemphasize an idea of persons as partial entities that exist across generations and intertwine with surrounding human and nonhuman environments. This formulation of the person as an environment differs from the epigenetic person-environment that feminist social scientists critical of epigenetics have to date discussed. While much important research has shown that epigenetic research and its representation in the popular press can further elaborate individualized maternal responsibility for the health of future generations, as with the term epigenetics itself, such research encompasses a wide variety of practices and approaches, taking place in increasingly varied geographic settings. In this article, and during my own ethnographic research, I have tried to remain attentive to both the ways in which epigenetic research practices and findings may continue a long line of medical practice and moral discourse that individualizes maternal responsibility for disease, as well as to the possibility that epigenetic research may simultaneously contest that very kind of individualization.

This contestation proves important because the kind of persons and environments brought into existence through epigenetic research have the potential to be translated by patients, the media, and even policymakers into ideas about who or what is responsible for exposures. In the DeTox Lab, this means responsibility for the conditions of toxicity potentially causing epigenetic alterations. By collecting multigenerational and multivariant evidence for the intergenerational transmission of epigenetic transformations, the DeTox Lab works through an understanding of persons as dividuals, thereby emphasizing a responsibility for toxic environments that goes beyond the mother, beyond her relatives, and into aspects of the physical, chemical, and sociocultural environments that surround and compose toxic lineages of exposure. These are environments that do not simply exist as stagnant surroundings, but have been shaped and formed through the past thirty-five years of China's social and economic change and industrial development. In the case of the DeTox Lab's research, an interdependent understanding of person-environment relatedness challenges the linear and individ- 
ualistic trajectories of both a strict Mendelian genetics and a changing postReform and Opening China.

The DeTox Lab's hope for epigenetic research on congenital disorders and reproductive health conditions is not that it will change maternal behaviors, lifestyle habits, or even personal exposure levels. Instead, the scientists pursue research to capture a much more complex picture of exposure, a more varied and elaborate toxicity linked to industrial development, and one that they fear has been and will continue to be inherited. Their epigenetic research constitutes a means through which a small group of scientists critical of the conditions of toxicity that surround them are able to provide evidence for what they see as the harmful nature of relentless economic development and lax industrial regulations. Furthermore, it is a scientific project figured in embodied reproductive consequences. Materialized in blood and bowel, epigenetic biomarkers of disease become a means for the DeTox Lab to relay to Chinese public health officials, and others open to listening, that the quality of China's future, and of future generations, is at stake.

\begin{abstract}
Through an ethnographic portrayal of the research on and treatment of congenital disorders in China, in this article I suggest that epigenetic research has the potential not only to exaggerate maternal blame but also to deindividualize ideas of maternal and parental responsibility. When a pregnant woman and the generations that produced her are understood through epigenetic studies as the environmental contexts of another person, responsibility has the potential to be reimagined as existing in relations and configurations that move beyond individualized understandings of personhood. Moreover, I argue that epigenetic models of development and inheritance at work in toxicological studies in China, and in the postgenomic embrace of complexity more generally, strongly resonate with existing social scientific models of Chinese life. Toxicologists conducting epigenetic research in China today reconfigure preexisting models of transgenerational, biosocial relationality to reassert a sense of social, environmental, and intergenerational connectivity in a moment of increasing individualization and chemical toxicity. [epigenetics; toxicity; environment; reproduction; individualism; China]
\end{abstract}

\title{
NOTES
}

Acknowledgments Research for this article was supported by funding from the WennerGren Foundation, the National Science Foundation, and the Social Science Research Council. This article benefited from the thoughtful feedback of many friends and colleagues at various stages, including Amber Benezra, Carrie Bond, Anna Jabloner, Bharat Venkat, Ayo Wahlberg, Haiyan Yang, and Joy Zhang, as well as that of my dissertation committee, Cori Hayden, Vincanne Adams, Lawrence Cohen, and Wen-Hsin Yeh. I received helpful questions and 
comments during presentations at the 2015 European Association for Social Anthropologists conference and Oxford University's Medical Anthropology Seminar, especially from Elisabeth Hsu and Amy McLennan. Feedback from the 2013 Council on Anthropology and Reproduction Graduate Student Paper Prize Committee was also insightful. Members of the Reproductive Sociology Research Group, especially Sarah Franklin, Katie Dow and Karen Jent, read and reread the manuscript in progress, providing essential encouragement throughout the publication process. The final product came together with much assistance from Cultural Anthropology's editorial collective, especially Cymene Howe, and from two anonymous reviewers who I thank for their time and attention. Of course, the article could not exist without the generosity of the scientists and physicians I shadowed and interviewed during fieldwork, and I express my sincere appreciation for their time and generosity during my stay in Nanjing.

1. All names of physicians, scientists, and institutions have been changed for privacy.

2. I borrow the term embedded from Jörg Niewöhner (2011), who argues that epigenetics moves the biological sciences away from the dominant notion of a skin-bound, autonomous, individualized body and toward a notion of "the embedded body" or the body in context.

3. For more on male preference, sex ratio, and the contemporary impact of the historical residue of patriarchy on China's demographics, see the extensive work of Susan Greenhalgh (1985, 2009, 2013; Greenhalgh and Li 1995).

4. Neural crest cells are embryonic cells that are pluripotent, or become many different types of cells, as they migrate during embryonic development. More so than other cell populations, these cells have been shown to carry epigenetic modifications across generations and are thought to be connected to epigenetically influenced disease development, as is the case with Hirschsprung's disease.

5. This research also opens up the potential for future diagnostic technologies. If the turning on or off of certain genes is found to correlate strongly with HD, then the diagnosis of this condition may become easier.

6. One could also argue that even during this time period, many scientists examined the ways in which processes of genetic inheritance were potentially influenced by environments, including Anne McLaren, who studied the uterine environment and maternal influence (Franklin 2007), and Barbara McClintock, who eventually won the Nobel Prize for her theory of genetic transposition (Keller 1984).

7. Here, Lysenkoism takes a position in a long line of characteristics that keep China from keeping pace with the West, from Confucianism in the work of Max Weber (1968) to feudalism in the work of John Fairbank (1953) to pseudoscience in the view of Yen Fu (Schwartz 1964).

8. Laurence Schneider's glorification of the return to Chinese genetics also masks the explicit and implicit relationships between science and politics in post-Reform and Opening China, as more recently researched by Margaret Sleeboom-Faulkner (2008) in the context of human cloning and stem cell research.

9. Such ideas have been discussed by anthropologists such as Francis Hsu (1971, 246), whose ethnographic account of kinship among the worldly and otherworldly in Yunnan Province shows how the virtuousness of worldly behaviors influences the fate of ancestors and the health of their descendants. Here, interactions between generations, living and dead, are "a matter of plain everyday behavior." On this point, see also Ahern 1978.

\section{REFERENCES}

Ahern, Emily M.

1978 “The Power and Pollution of Chinese Women." In Studies in Chinese Society, edited Anagnost, Ann by Arthur P. Wolf, 269-90. Stanford, Calif.: Stanford University Press.

2004 “The Corporeal Politics of Quality (Suzhi).” Public Culture 16, no. 2: 189-208. http://dx.doi.org/10.1215/08992363-16-2-189. 
Chen, Nancy N.

2003 Breathing Spaces: Qigong, Psychiatry, and Healing in China. New York: Columbia University Press.

Chin, Tai-Wai, Chih-Yang Chiu, Hsin-Lin Tsai, Chin-Su Liu, Chou-Fu Wei, and Tjin-Shing Jap

2008 "Analysis of the RET Gene in Subjects with Sporadic Hirschsprung's Disease." Journal of the Chinese Medical Association 71, no. 8: 406-10. http://dx.doi.org/

Choy, Timothy 10.1016/S1726-4901(08)70091-1.

2011 Ecologies of Comparison: An Ethnography of Endangerment in Hong Kong. Durham, N.C.: Duke University Press.

Clarke, Adele E., Janet K. Shim, Laura Mamo, Jennifer Ruth Fosket, and Jennifer R.

Fishman

2003 "Biomedicalization: Technoscientific Transformations of Health, Illness, and U.S. Biomedicine.” American Sociological Review 68, no. 2: 161-94. http://dx.doi.org/ $10.2307 / 1519765$.

Dikötter, Frank

1992 The Discourse of Race in Modern China. London: Hurst.

1998 Imperfect Conceptions: Medical Knowledge, Birth Defects, and Eugenics in China. New York: Columbia University Press.

Emison, Eileen Sproat, Andrew S. McCallion, Carl S. Kashuk, Richard T. Bush, Elizabeth Grice, Shin Lin, Matthew E. Portnoy, David J. Cutler, Eric D. Green, and Aravinda

Chakravarti

2005 "A Common Sex-Dependent Mutation in a RET Enhancer Underlies Hirschsprung Disease Risk.” Nature 434: 857-63. http://dx.doi.org/10.1038/ nature03467.

Fairbank, John King

1953 Trade and Diplomacy on the China Coast: The Opening of the Treaty Ports, 18421854. Stanford, Calif.: Stanford University Press.

Farquhar, Judith

2002 Appetites: Food and Sex in Postsocialist China. Durham, N.C.: Duke University Press.

Fei, Xiaotong

1992 From the Soil: The Foundations of Chinese Society. Translated by Gary G. Hamilton and Wang Zheng. Berkeley: University of California Press. Originally published in 1947.

Franklin, Sarah

1995 "Postmodern Procreation: A Cultural Account of Assisted Reproduction." In Conceiving the New World Order: The Global Politics of Reproduction, edited by Faye D. Ginsburg and Rayna Rapp, 323-45. Berkeley: University of California Press.

2007 “Obituary: Dame Dr. Anne McLaren.” Regenerative Medicine 2, no. 5: 853-59. http://dx.doi.org/10.2217/17460751.2.5.853.

Franklin, Sarah, and Celia Roberts

2006 Born and Made: An Ethnography of Preimplantation Genetic Diagnosis. Princeton, N.J.: Princeton University Press.

Goodman, Alan H., Deborah Heath, and M. Susan Lindee, eds.

2003 Genetic Nature/Culture: Anthropology and Science Beyond the Two-Culture Divide. Berkeley: University of California Press.

Greenhalgh, Susan

1985 "Sexual Stratification: The Other Side of 'Growth with Equity' in East Asia." Population and Development Review 11, no. 2: 265-314. http://dx.doi.org/ $10.2307 / 1973489$.

2008 Just One Child: Science and Policy in Deng's China. Berkeley: University of California Press. 
2009 "The Chinese Biopolitical: Facing the Twenty-First Century." New Genetics and Society 28, no. 3: 205-22. http://dx.doi.org/10.1080/14636770903151992.

2013 "Patriarchal Demographics? China's Sex Ratio Reconsidered." Population and Development Review 38, S1: 130-49. http://dx.doi.org/10.1111/j.17284457.2013.00556.x

Greenhalgh, Susan, and Jiali Li

1995 "Engendering Reproductive Policy and Practice in Peasant China: For a Feminist Demography of Reproduction.” Signs 20, no. 3: 601-41. http://www.jstor. org/stable/3174835.

Guthman, Julie, and Becky Mansfield

2013 "The Implications of Environmental Epigenetics: A New Direction for Geographic Inquiry on Health, Space, and Nature-Society Relations." Progress in Human Geography 37, no. 4: 486-504. http://dx.doi.org/10.1177/ 0309132512463258 .

Haraway, Donna J.

1991 Simians, Cyborgs, and Women: The Reinvention of Nature. New York: Routledge. Hedlund, Maria

2012 "Epigenetic Responsibility." Medicine Studies 3, no. 3: 171-83. http://dx.doi. org/10.1007/s12376-011-0072-6.

Hsu, Francis L. K.

1971 Under the Ancestors' Shadow: Kinship, Personality, and Social Mobility in China. Stanford, Calif.: Stanford University Press. Originally published in 1948.

Ingold, Tim, and Gisli Pálsson, eds.

2013 Biosocial Becomings: Integrating Social and Biological Anthropology. New York: Cambridge University Press.

Jablonka, Eva, and Marion J. Lamb

1999 Epigenetic Inheritance and Evolution: The Lamarckian Dimension. New York: Oxford University Press.

Keller, Evelyn Fox

1984 A Feeling for the Organism: The Life and Work of Barbara McClintock. Tenth anniversary edition. New York: Henry Holt.

2002 The Century of the Gene. Cambridge, Mass.: Harvard University Press.

2010 The Mirage of a Space between Nature and Nurture. Durham, N.C.: Duke University Press.

Kleinman, Arthur

1981 Patients and Healers in the Context of Culture: An Exploration of the Borderland between Anthropology, Medicine, and Psychiatry. Berkeley: University of California Press.

Kleinman, Arthur, Yunxiang Yan, Jing Jun, Sing Lee, and Everett Zhang

2011 Deep China: The Moral Life of the Person. Berkeley: University of California Press. Lamoreaux, Janelle

2013 "Infertile Futures: Sperm and Science in a Chinese Environment." PhD dissertation, University of California, Berkeley and University of California, San Francisco.

Landecker, Hannah

2011 "Food as Exposure: Nutritional Epigenetics and the New Metabolism." BioSocieties 6, no. 2: 167-94. http://dx.doi.org/10.1057/biosoc.2011.1.

2014 "Pregnancy: Study the Mother's DNA as Well." Nature 513: 172. http://dx. doi.org/10.1038/513172b.

Landecker, Hannah, and Aaron Panofsky

2013 "From Social Structure to Gene Regulation and Back: A Critical Introduction to Environmental Epigenetics for Sociology." Annual Review of Sociology 39, no. 1:

Li, Ching Chun 333-57. http://dx.doi.org/10.1146/annurev-soc-071312-145707.

1950 "Genetics Dies in China." Journal of Heredity 41, no. 4: 91. http://jhered. oxfordjournals.org/content/41/4/90.extract. 
Liu, Xin

2002 The Otherness of Self: A Genealogy of the Self in Contemporary China. Ann Arbor: University of Michigan Press.

2012 The Mirage of China: Anti-Humanism, Narcissism, and Corporeality of the Contemporary Lock, Margaret World. New York: Berghahn.

2007 "The Future Is Now." In Biomedicine As Culture: Instrumental Practices, Technoscientific Knowledge, and New Modes of Life, edited by Regula Valérie Burri and Joseph Dumit, 61-86. New York: Routledge.

2015 "Comprehending the Body in the Era of the Epigenome." Current Anthropology 56, no. 2: 151-77. http://dx.doi.org/10.1086/680350.

Lock, Margaret, and Judith Farquhar

2007 Beyond the Body Proper: Reading the Anthropology of Material Life. Durham, N.C.: Duke University Press.

Lora-Wainwright, Anna

2013 Fighting for Breath: Living Morally and Dying of Cancer in a Chinese Village. Honolulu: University of Hawai'i Press.

Lysenko, Trofim D.

2001 Heredity and Its Variability. Honolulu: University Press of the Pacific. Originally published in 1951.

Mackendrick, Norah

2014 "More Work for Mother: Chemical Body Burdens as a Maternal Responsibility." Gender and Society 28, no. 5: 705-28. http://dx.doi.org/10.1177/ 0891243214529842 .

Mansfield, Becky

2012 "Race and the New Epigenetic Biopolitics of Environmental Health." BioSocieties 7, no. 4: 352-72. http://dx.doi.org/10.1057/biosoc.2012.22.

Mansfield, Becky, and Julie Guthman

2015 "Epigenetic Life: Biological Plasticity, Abnormality, and New Configurations of Race and Reproduction.” Cultural Geographies 22, no. 1: 3-20. http:// dx.doi.org/10.1177/1474474014555659.

Mol, Annemarie

2002 The Body Multiple: Ontology in Medical Practice. Durham, N.C.: Duke University Press.

Niewöhner, Jörg

2011 "Epigenetics: Embedded Bodies and the Molecularization of Biography and Milieu." BioSocieties 6, no. 3: 279-98. http://dx.doi.org/10.1057/biosoc. 2011.4.

Pálsson, Gísli

2007 Anthropology and the New Genetics. New York: Cambridge University Press.

People's Republic of China Ministry of Health

2011 "Report on Women and Children's Health Development in China." August. http://www.gov.cn/gzdt/att/att/site1/20110921/

001e3741a4740fe3bdbf02.pdf.

Petchesky, Rosalind Pollack

1987 "Fetal Images: The Power of Visual Culture in the Politics of Reproduction." Feminist Studies 13, no. 2: 263-92. http://dx.doi.org/10.2307/3177802.

Pickersgill, Martyn, Jörg Niewöhner, Ruth Müller, Paul Martin, and Sarah CunninghamBurley

2013 "Mapping the New Molecular Landscape: Social Dimensions of Epigenetics." New Genetics and Society 32, no. 4: 429-47. http://dx.doi.org/10.1080/ 14636778.2013.861739.

Raffles, Hugh

2007 “Jews, Lice, and History." Public Culture 19, no. 3: 521-66. http://dx.doi.org/ 10.1215/08992363-2007-008. 
Rapp, Rayna

1999 Testing Women, Testing the Fetus: The Social Impact of Amniocentesis in America. New York: Routledge.

2005 “Comment on Margaret Lock's 'Eclipse of the Gene and the Return of Divination.” Current Anthropology 46, S5: S64 65. http://dx.doi.org/10.1086/ 432452.

Richardson, Sarah S., Cynthia R. Daniels, Matthew W. Gillman, Janet Golden, Rebecca

Kukla, Christopher Kuzawa, and Janet Rich-Edwards

2014 “Society: Don't Blame the Mothers.” Nature 512: 131-32. http://dx.doi.org/ 10.1038/512131a.

Rofel, Lisa

2007 Desiring China: Experiments in Neoliberalism, Sexuality, and Public Culture. Durham, N.C.: Duke University Press.

Rose, Nikolas

2009 The Politics of Life Itself: Biomedicine, Power, and Subjectivity in the Twenty-First Century. Princeton, N.J.: Princeton University Press.

Scheper-Hughes, Nancy, and Margaret M. Lock

1987 "The Mindful Body: A Prolegomenon to Future Work in Medical Anthropology." Medical Anthropology Quarterly 1, no. 1: 6-41. http://dx.doi.org/10.1525/ maq.1987.1.1.02a00020.

Schneider, Laurence A.

1989 "Learning from Russia: Lysenkoism and the Fate of Genetics in China, 19501986." In Science and Technology in Post-Mao China, edited by Denis Fred Simon and Merle Goldman, 45-65. Cambridge, Mass.: Harvard University Press.

Schwartz, Benjamin

1964 In Search of Wealth and Power: Yen Fu and the West. Cambridge, Mass.: Harvard University Press.

Shapiro, Judith

2001 Mao's War against Nature: Politics and the Environment in Revolutionary China. New York: Cambridge University Press.

Sleeboom-Faulkner, Margaret

2008 "The Changing Nature of Ideology in the Life Sciences in Mainland China: CaseStudies of Human Cloning and Human Embryonic Stem Cell Research (hESR) in Medical Textbooks, 1996-2005.” BioSocieties 3, no. 1: 21-36. http:// dx.doi.org/10.1017/S1745855208005930.

Stern, Alexandra Minna

2005 Eugenic Nation: Faults and Frontiers of Better Breeding in Modern America. Berkeley: University of California Press.

Strathern, Marilyn

1991 "Partners and Consumers: Making Relations Visible." New Literary History 22, no. 3: 581-601. http://dx.doi.org/10.2307/469205.

Thompson, Charis

2005 Making Parents: The Ontological Choreography of Reproductive Technologies. Cambridge, Mass.: MIT Press.

$\mathrm{Tu}$, Weiming

2001 "The Ecological Turn in New Confucian Humanism: Implications for China and the World.” Daedalus 130, no. 4: 243-64. https://www.amacad.org/content/ publications / pubContent.aspx?d $=1300$

U.S. National Institute of Health

2012 "Hirschsprung Disease." Genetics Home Reference. http://ghr.nlm.nih.gov/ condition/hirschsprung-disease.

Waddington, Conrad $\mathrm{H}$.

2012 “The Epigenotype.” International Journal of Epidemiology 41, no. 1: 10-13. http:// dx.doi.org/10.1093/ije/dyr184. Originally published in 1942. 
Warin, Megan, Tanya Zivkovic, Vivienne Moore, and Michael Davies

2012 "Mothers as Smoking Guns: Fetal Overnutrition and the Reproduction of Obesity." Feminism and Psychology 22, no. 3: 360-75. http://dx.doi.org/10. $1177 / 0959353512445359$.

Weber, Max

1968 The Religion of China: Confucianism and Taoism. Translated by Hans H. Gerth. New York: Free Press. Originally published in 1915.

Yan, Yunxiang

2009 The Individualization of Chinese Society. New York: Berg.

Yang, Mayfair Mei-hui

1994 Gifts, Favors, and Banquets: The Art of Social Relationships in China. Ithaca, N.Y.:

Zhan, Mei

Cornell University Press.

2011 "Worlding Oneness: Daoism, Heidegger, and Possibilities for Treating the Human.” Social Text 29, no. 4: 107-28. http://dx.doi.org/10.1215/016424721416109.

Zhang, Everett Yuehong

2015 The Impotence Epidemic: Men's Medicine and Sexual Desire in Contemporary China. Durham, N.C.: Duke University Press.

Zhu, Jianfeng

2013 "Projecting Potentiality: Understanding Maternal Serum Screening in Contemporary China." Current Anthropology 54, S7: S36-44. http://dx.doi.org/ 10.1086/670969. 